\title{
$\beta$-Adrenoceptor Activation in Breast MCF-10A Cells Induces a Pattern of Catecholamine Production Similar to that of Tumorigenic MCF-7 Cells
}

\author{
Filipa Amaro ${ }^{1, \dagger}{ }^{+}$Dany Silva ${ }^{1, \dagger}{ }^{+}$Henrique Reguengo ${ }^{2,3}$, José C. Oliveira ${ }^{2,3}$ (D) Clara Quintas ${ }^{1,4}$, \\ Nuno Vale ${ }^{1,4}\left(\mathbb{D}\right.$, Jorge Gonçalves ${ }^{1,4, *}$ and Paula Fresco ${ }^{1,4}$ (i) \\ 1 Laboratory of Pharmacology, Department of Drug Sciences, Faculty of Pharmacy, University of Porto, \\ 4050-313 Porto, Portugal; famaro@ff.up.pt (F.A.); up201708266@fc.up.pt (D.S.); claraquintas@ff.up.pt (C.Q.); \\ nuno.vale@ff.up.pt (N.V.); pfresco@ff.up.pt (P.F.) \\ 2 Clinical Chemistry, Department of Laboratory Pathology, Centro Hospitalar Universitário do Porto (CHUP), \\ 4099-001 Porto, Portugal; henrique.reguengo.sqc@chporto.min-saude.pt (H.R.); \\ director.sqc@chporto.min-saude.pt (J.C.O.) \\ 3 Unit for Multidisciplinary Research in Biomedicine (UMIB), \\ Institute of Biomedical Sciences Abel Salazar (ICBAS), University of Porto, 4050-313 Porto, Portugal \\ 4 Epithelial Interactions in Cancer, I3S, University of Porto, 4200-135 Porto, Portugal \\ * Correspondence: jgoncalves@ff.up.pt \\ + These authors contributed equally to this work.
}

Received: 3 September 2020; Accepted: 25 October 2020; Published: 27 October 2020

check for updates

\begin{abstract}
Adrenaline, which participates in the neuroendocrine response that occurs during stress and perimenopause, may be tumorigenic. This exploratory study aimed at investigating whether non-tumorigenic and tumorigenic human breast epithelial cell lines are able to synthesize adrenaline. The study was carried out in non-tumorigenic (MCF-10A) and tumorigenic (MCF-7) human breast cell lines. Expression of enzymes involved in adrenaline synthesis was characterized by RT-qPCR, immunocytochemistry and western blot. Catecholamines and analogue compounds were quantified by HPLC-ECD. Functional assessment of the impact of drugs on cells' tumorigenic potential was assessed by determination of cell viability and clonogenic ability. Both MCF-10A and MCF-7 cells produce catecholamines, but the capacity to produce adrenaline is lower in MCF-10A cells. $\beta$-adrenoceptor activation increases the capacity of MCF-10A cells to produce adrenaline and favor both cell viability and colony formation. It is concluded that exposure of human breast epithelial cells to $\beta$-adrenoceptor agonists increases cell proliferation and the capacity to produce adrenaline, creating an autocrine potential to spread these adrenergic effects in a feed-forward loop. It is conceivable that these effects are related to tumorigenesis, bringing a new perspective to understand the claimed anticancer effects of propranolol and the increase in breast cancer incidence caused by stress or during perimenopause.
\end{abstract}

Keywords: breast cancer; $\beta$-adrenoceptors; catecholamine synthesis; tumorigenic process; propranolol

\section{Introduction}

Exposure to major stressful events is associated with higher breast cancer risk [1,2] and with lower survival rates in patients with breast cancer [3]. The main stress response mechanisms are the activation of the hypothalamic-pituitary-adrenal axis, with a consequent increase in plasmatic cortisol levels and the activation of the sympathetic nervous system (SNS). SNS activation is accompanied by a long-lasting increase of the catecholamines, noradrenaline, and adrenaline, in plasma [4]. An increase in plasma catecholamines also occur during perimenopause, which seems to contribute to the cardiovascular 
changes accompanying hot flashes [5,6]. Noradrenaline and adrenaline orchestrate a fight or flight response (increased cardiac output, energy mobilization to the periphery, increased awareness state) typical of the reaction to acute stress. They may also promote other types of biological processes, some favorable to tumorigenesis/carcinogenesis, namely stimulation of cancer cell proliferation [7] and inhibition of immune surveillance $[8,9]$.

The first evidence of a link between adrenergic stimulation and carcinogenesis dates back to the middle of last century, after the observation that local injection of adrenaline increased the rate of tumor formation [10]. Further studies corroborated this link by showing that adrenergic stimulation induces proliferation of colon cancer cells [11], growth of colorectal carcinoma in vivo [12], and migration of carcinoma cells from colon [13], nasopharynx [14], prostate [15] and pancreas [16].

Adrenaline and noradrenaline effects are mediated by a family of G-protein coupled receptors, named adrenoceptors [17]. Adrenoceptors are subdivided into three major types $\left(\alpha_{1}, \alpha_{2}\right.$, and $\beta)$, each further divided into three subtypes $\left(\alpha_{1 A}, \alpha_{1 B}, \alpha_{1 D} ; \alpha_{2 A}, \alpha_{2 B}, \alpha_{2 C} ;\right.$ and $\beta_{1}, \beta_{2}$, and $\left.\beta_{3}\right)$. Adrenoceptors from the three types $\left(\alpha_{1}, \alpha_{2}\right.$, and $\left.\beta\right)$ are involved in the adrenergic modulation of carcinogenesis $[9,18]$. The type involved in this modulation may differ according to the tissue: $\alpha_{1}$-adrenoceptors increase proliferation of gastric [19] and prostate [20] cancer cells; $\alpha_{2}$-adrenoceptors increase proliferation of breast cancer cells [21,22], whereas $\beta$-adrenoceptors, mainly $\beta_{2}$, seem to increase cell proliferation of lung [23,24], breast [25,26], ovarian [27], pancreas [28], colon [11] cancer and of melanoma cells $[9,29]$. Observational studies have shown that blockade of $\beta$-adrenoceptors increase overall survival in cancer patients [30,31], indicating the existence of $\beta$-adrenoceptor-mediated effects with clinical relevance in the modulation of carcinogenesis.

It is generally assumed that the adrenoceptor endogenous agonists, noradrenaline, and adrenaline, involved in tumor regulation have a neuroendocrine origin, and that $\beta$-blockers would reduce cancer mortality by blocking a putative carcinogenic effect of the catecholamines released from the sympathetic nerves or from the adrenal medulla [32,33]. Although tumors may recruit sympathetic adrenergic nerves [34], the possibility that tumor cells may also contribute to the catecholamine pool must also be considered. It was recently reported that human breast epithelial cells express tyrosine hydroxylase (TH; the rate-limiting enzyme of catecholamine synthesis) and produce noradrenaline, described as a putative mechanism for the stress-induced changes in milk composition [35]. Moreover, transfected breast tumorigenic cells (MCF-7 overexpressing Her-2) were also reported to produce catecholamines [36]. The possibility that catecholamines involved in carcinogenesis could be formed locally deserves to be further explored because it opens the hypothesis that, at least in breast tissue, the adrenergic-induced carcinogenesis may have an autocrine contribution. In the present study, this hypothesis was explored by investigating whether breast cells that differ in their tumorigenic potential (non-tumorigenic MCF-10A, and tumorigenic MCF-7 cells), (i) possess the ability to synthesize catecholamines, (ii) if there are differences in the synthetic ability according to the cell tumorigenic potential and (iii) if this ability is influenced by exogenous $\beta$-adrenoceptor ligands (to clarify a putative contribution of this mechanism for the reduction of breast cancer incidence and mortality caused by $\beta$-blockers).

\section{Results}

\subsection{Expression of Enzymes Involved in the Biosynthesis of Catecholamines}

To address whether human breast non-tumorigenic MCF-10A and tumorigenic MCF-7 cells express the enzymatic machinery responsible for the biosynthesis of catecholamines, expression of TH (the rate-limiting enzyme of catecholamine synthesis) and phenylethanolamine N-methyltransferase (PNMT, the enzyme that converts noradrenaline to adrenaline), was investigated in these two cell lines by RT-qPCR and by immunocytochemistry.

As shown (Figure 1), mRNA for TH and PNMT was found both in MCF-10A and in MCF-7 cells indicating the existence of a transcription process operating for the TH and PNMT genes in both cell lines. However, there was a marked difference in the two cell lines: the mRNA levels of TH were much 
higher in the tumorigenic MCF-7 cells, compared to that observed in the non-tumorigenic MCF-10A cells (Figure 1a); mRNA levels of PNMT were also higher in MCF-7 cells (Figure 1b) but much lower than those of TH in both cell lines.

(a)

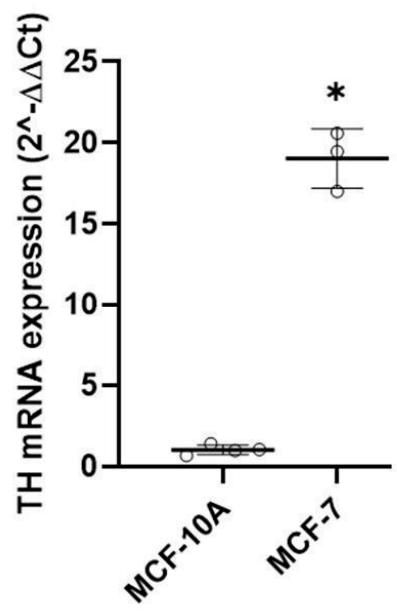

(b)

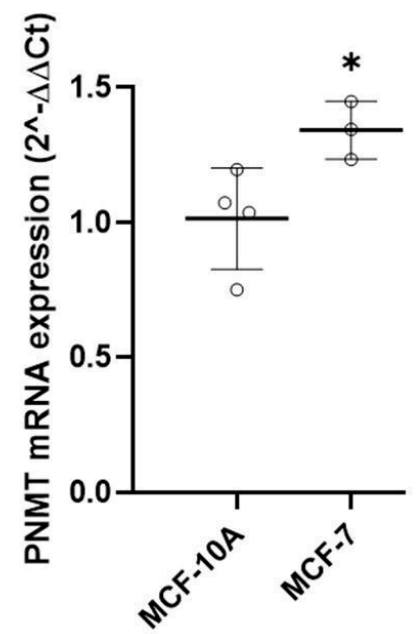

Figure 1. mRNA expression of (a) tyrosine hydroxylase (TH) and (b) phenylethanolamine N-methyltransferase (PNMT), in MCF-10A and MCF-7 cells, determined using RT-qPCR and normalized to $\beta$-actin (Ct values for $\beta$-actin are available in Figure S1). Similar results were obtained when normalized to GAPDH. Values are means \pm SD from 3 (MCF-10A cells) or 4 (MCF-7 cells) independent experiments. Significant differences from TH or PNMT expression in MCF-10A cells: ${ }^{*} p \leq 0.05$ (Student's $t$-test).

Expression of TH and PNMT was further proceeded to investigate protein expression by immunocytochemistry. Both MCF-10A and MCF-7 cells presented immunoreactivities for anti-TH and anti-PNMT antibodies, absent in the negative controls (Figure 2), indicating that transcription proceeds to the translation of both enzymes (TH and PNMT) in the two cell lines.

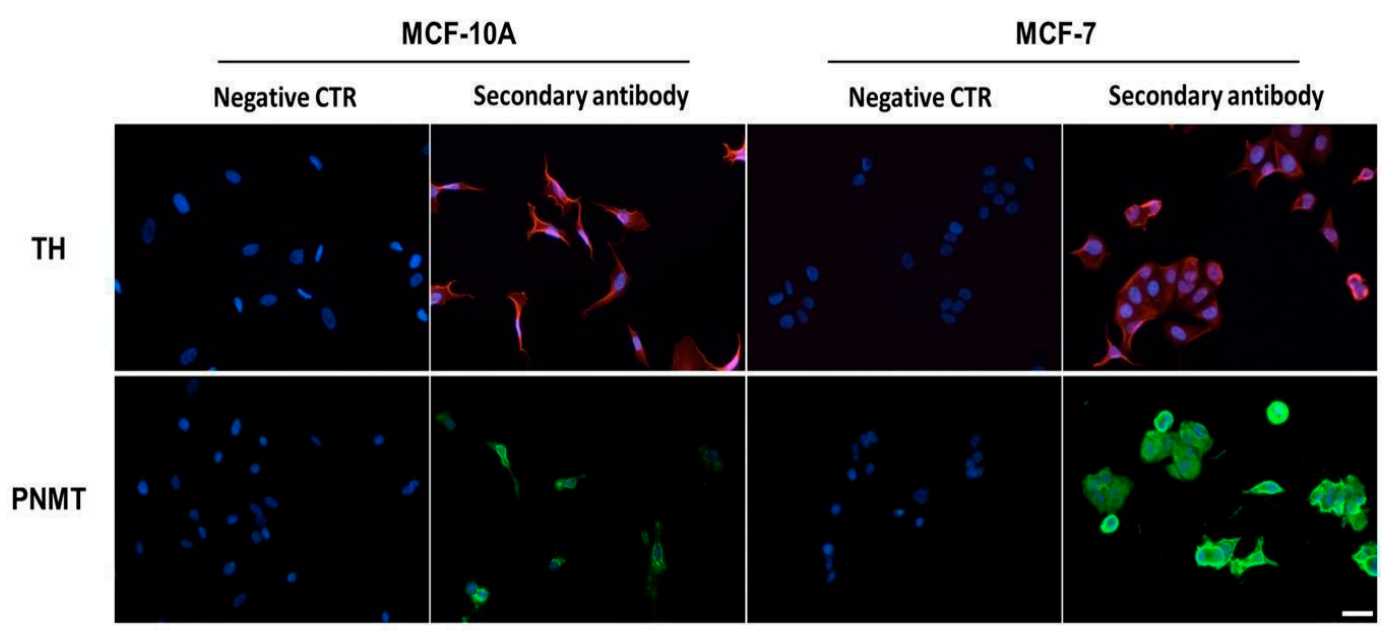

Figure 2. Protein expression of tyrosine hydroxylase $(\mathrm{TH})$ and phenylethanolamine $\mathrm{N}$-methyltransferase (PNMT) in MCF-10A or in MCF-7 cells, revealed by immunocytochemistry. Shown are representative microphotographs of immunoreactivities revealed by secondary antibodies conjugated with Alexa fluor 594 (red fluorescence, TH) or with Alexa fluor 488 (green fluorescence, PNMT). Nuclei were labelled with Hoechst 33342 (blue fluorescence). Scale bar: $20 \mu \mathrm{m}$. Negative control (CTR): without primary antibody. 


\subsection{Catecholamines Biosynthesis}

The ability of cells to synthesize catecholamines was assessed by looking for the presence of endogenous catecholamines, both in the cellular fraction and in the conditioned medium of both cell lines.

This ability was further assessed by incubating the cells with an exogenous substrate ( $\alpha$-methylDOPA). Although not dependent on TH, $\alpha$-methylDOPA can be metabolized by the enzymes of the catecholamine biosynthesis pathway (DOPA decarboxylase, dopamine $\beta$-hydroxylase and PNMT). Therefore, the presence of $\alpha$-methyl derivatives of endogenous catecholamines in the cell's conditioned media may be taken as a strong indicator of a fully operating system in these cell lines. The endogenous catecholamines and $\alpha$-methylDOPA metabolites were detected by LC-MS (Figure S2) and/or quantified by HPLC-ECD. Culture media, without cells, were kept in the same incubation conditions and used as controls.

In the cellular fraction of MCF-10A or MCF-7 cells, as well as in medium without cells (controls), noradrenaline and adrenaline were not detected. However, both catecholamines were present in the conditioned medium of both cell lines (Table 1). The MCF-7 cells adrenaline/noradrenaline ratio was higher than that of MCF-10A cells (about 5.8 and 0.9, respectively), indicating that MCF-7 cells produce mainly adrenaline.

Table 1. Concentrations of noradrenaline and adrenaline in the conditioned medium of MCF-10A and MCF-7 cells, determined by HPLC-ECD.

\begin{tabular}{ccc}
\hline & Noradrenaline (nM) & Adrenaline (nM) \\
\hline MCF-10A cells & $1.78 \pm 0.36$ & $1.65 \pm 0.29$ \\
\hline MCF-7 cells & $1.89 \pm 0.51$ & $11.02 \pm 1.05^{*}$ \\
\hline
\end{tabular}

Conditioned media were collected after a 24-h exposure period. Experiments were carried out in foetal bovine serum-free medium, to avoid interferences from serum catecholamines. Negative controls were carried out in medium without cells and, under these conditions, neither noradrenaline nor adrenaline were detected in the medium. Shown are means \pm SEM of 5 independent experiments. Significant differences from MCF-10A cells: ${ }^{*} p \leq 0.05$ (Student's $t$-test).

To confirm the presence of an operational catecholamine synthetic pathway in MCF-10A and MCF-7 cells, both cell lines were exposed to 10 or $100 \mu \mathrm{M} \alpha$-methylDOPA. After a 24-h exposure of cells to $\alpha$-methylDOPA, this pseudo-substrate was no longer detected in the conditioned medium of either MCF-10A or MCF-7 cells. However, its metabolite ( $\alpha$-methylnoradrenaline) was detected in the conditioned media of both cell lines and the concentration of $\alpha$-methylnoradrenaline was even higher when cells were exposed to the higher concentration $(100 \mu \mathrm{M})$ of $\alpha$-methylDOPA (Table 2). LC-MS assays confirmed the presence of chemical entities with molecular weights corresponding to successive methylations of $\alpha$-methylnoradrenaline in the conditioned medium of MCF-7 cells (Figure S2).

Table 2. Capacity of non-tumorigenic (MCF-10A) and tumorigenic (MCF-7) breast cells to metabolize $\alpha$-methylDOPA.

\begin{tabular}{ccc}
\hline & MCF-10A Cells [ $\alpha$-methylNA (nM)] & MCF-7 Cells [ $\alpha$-methylNA (nM)] \\
\hline $\mathbf{1 0} \boldsymbol{\mu M} \boldsymbol{\alpha}$-methylDOPA & $165.4 \pm 8.9$ & $11.0 \pm 1.1^{*}$ \\
$\mathbf{1 0 0} \boldsymbol{\mu M} \boldsymbol{\alpha}$-methylDOPA & $316.3 \pm 6.7$ & $46.1 \pm 2.8^{*}$ \\
\hline
\end{tabular}

Conditioned media were collected after a 24-h exposure period to $10 \mu \mathrm{M}$ or $100 \mu \mathrm{M} \alpha$-methylDOPA. Negative controls consisted of culture medium without $\alpha$-methylDOPA, processed in parallel. Shown are means \pm SEM of 4 independent experiments. Significant differences from MCF-10A cells exposed to the same $\alpha$-methylDOPA concentration: ${ }^{*} p \leq 0.05$ (Student's $t$-test). $\alpha$-methylNA: $\alpha$-methylnoradrenaline.

The lower concentration of $\alpha$-methylnoradrenaline in the conditioned medium of MCF-7 cells, comparatively to that of MCF-10A cells initially exposed to the same concentration of $\alpha$-methylDOPA $(10$ or $100 \mu \mathrm{M})$, suggests that the metabolization of $\alpha$-methylnoradrenaline into $\alpha$-methyladrenaline 
occurs at a higher rate in MCF-7 cells (Table 2). This finding is in agreement with the higher PNMT mRNA expression found in MCF-7 cells (Figure 1). Taken together, these results provide additional evidence to support the existence of an operational catecholamine biosynthetic pathway in both cell lines, albeit more efficient in MCF-7 cells.

\subsection{Influence of $\beta$-Adrenergic Receptor Activation}

Increased cell viability and colony formation are parameters accepted to be hallmarks of tumorigenesis [37]. Therefore, the MTT and the clonogenic assays were used to explore the effects of adrenoceptor activation in both MCF-10A and MCF-7 cells. Because of the recognized protective effects of $\beta$-blockers in breast cancer [31] and of the role of $\beta_{2}$-adrenoceptors in the modulation of breast cancer cell proliferation $[25,26]$, the experimental approach was designed to target $\beta_{2}$-adrenoceptor, which expression was confirmed in both MCF-10A and MCF-7 cell lines (Figure S3). Pharmacological interference with the $\beta$-adrenoceptors was based on the use of the $\beta$-adrenoceptor agonist, isoprenaline, and on the $\beta$-adrenoceptor antagonists, propranolol (non-selective) and ICI 118,551 (selective for the $\beta_{2}$-adrenoceptor subtype).

\subsubsection{Cell Viability}

The effects of the adrenergic ligands in the viability of non-tumorigenic MCF-10A cells are shown in Figure 3. After a 24-h exposure period, isoprenaline $(0.1,10 \mu \mathrm{M})$ increased the viability of MCF-10A cells (Figure 3). Propranolol or ICI 118,551 $(1 \mu \mathrm{M})$, per se, had no effect on cell viability $(98.9 \pm 10.4 \%$ and $106.8 \pm 4.8 \% ; n=4$, respectively) even when high concentrations $(100 \mu \mathrm{M})$ were used $(101.6 \pm 13.7 \%$ and $100.8 \pm 6.2 \% ; n=5$, respectively). Cell viability was also not altered by prazosin $(1 \mu \mathrm{M})$ or by yohimbine $(1 \mu \mathrm{M})$, antagonists of $\alpha_{1}$ - and $\alpha_{2}$-adrenoceptors, respectively.

When combined with isoprenaline $(0.1,10 \mu \mathrm{M}$ ), both propranolol (Figure 3a) and ICI 118,551 (Figure 3b) prevented the increase in cell viability caused by isoprenaline. Since ICI 118,551 is a selective antagonist for the $\beta_{2}$-adrenoceptor subtype, these results indicate a putative involvement of the $\beta_{2}$-adrenoceptor subtype in the increase of the viability of MCF-10A cells.

In MCF-7 cells, isoprenaline $(0.1,10 \mu \mathrm{M})$ exposure during $24 \mathrm{~h}$ did not change cell viability (Figure $3 c, d)$. The $\beta$-antagonists propranolol or ICI 118,551 $(1 \mu \mathrm{M})$, per se, had no effect on cell viability $(91.6 \pm 15.6 \%$ and $101.6 \pm 20.5 \% ; n=5$, respectively) and did not alter the effects of isoprenaline after a 24-h exposure (Figure $3 c, d)$. The $\alpha_{1}$-adrenoceptor antagonist prazosin $(1 \mu \mathrm{M})$ also did not alter cell viability. However, yohimbine $(1 \mu \mathrm{M})$, the $\alpha_{2}$-adrenoceptor antagonist, reduced cell viability (to $81.2 \pm 7.1 \% ; n=5 ; p \leq 0.05$.

An increase of the incubation time from 24 to $72 \mathrm{~h}$ was able to reveal an inhibitory effect of $10 \mu \mathrm{M}$ isoprenaline (to $59.8 \pm 2.9 \% ; n=4 ; p \leq 0.05$ ). Inhibition of cell viability was also observed when the concentration of propranolol was increased to $100 \mu \mathrm{M}$ and the incubation time kept at $24 \mathrm{~h}$ (to $54.3 \pm 14.0 \% ; n=5 ; p \leq 0.05$ ). A similar effect was observed with $100 \mu \mathrm{M}$ ICI 118,551 (to $31.3 \pm 2.5 \%$; $n=5 ; p \leq 0.05)$.

Taken together, these results show that adrenoceptors influence the viability of the tumorigenic MCF-7 cells in a manner distinct from that of the non-tumorigenic MCF-10A cells, presenting and odd profile in which exogenous $\beta$-adrenoceptor agonists and antagonists seem to elicit the same type of response.

\subsubsection{Clonogenic Ability}

Further characterization of potential tumorigenic effects elicited by $\beta$-adrenergic receptor activation was performed using clonogenic assays. The effects on the number of colonies were evaluated after incubation with the indicated drugs for seven days (Figure 4). Images of a representative experiment with MCF-10A cells are shown in Figure 4a. Colony quantification showed that the $\beta$-adrenoceptor agonist isoprenaline $(10 \mu \mathrm{M})$ markedly increased the number of colonies formed. The $\beta$-adrenoceptor antagonists, propranolol or ICI 118,551 (both at $1 \mu \mathrm{M}$ ), per se, had no effect on the number of MCF-10A 
colonies formed. However, when combined with isoprenaline $(10 \mu \mathrm{M})$, both $1 \mu \mathrm{M}$ propranolol and $1 \mu \mathrm{M}$ ICI 118,551 prevented the increase in the number of colonies caused by isoprenaline (Figure $4 \mathrm{~b}$ ). These results are in line with those obtained in the viability assays (see Figure 3).
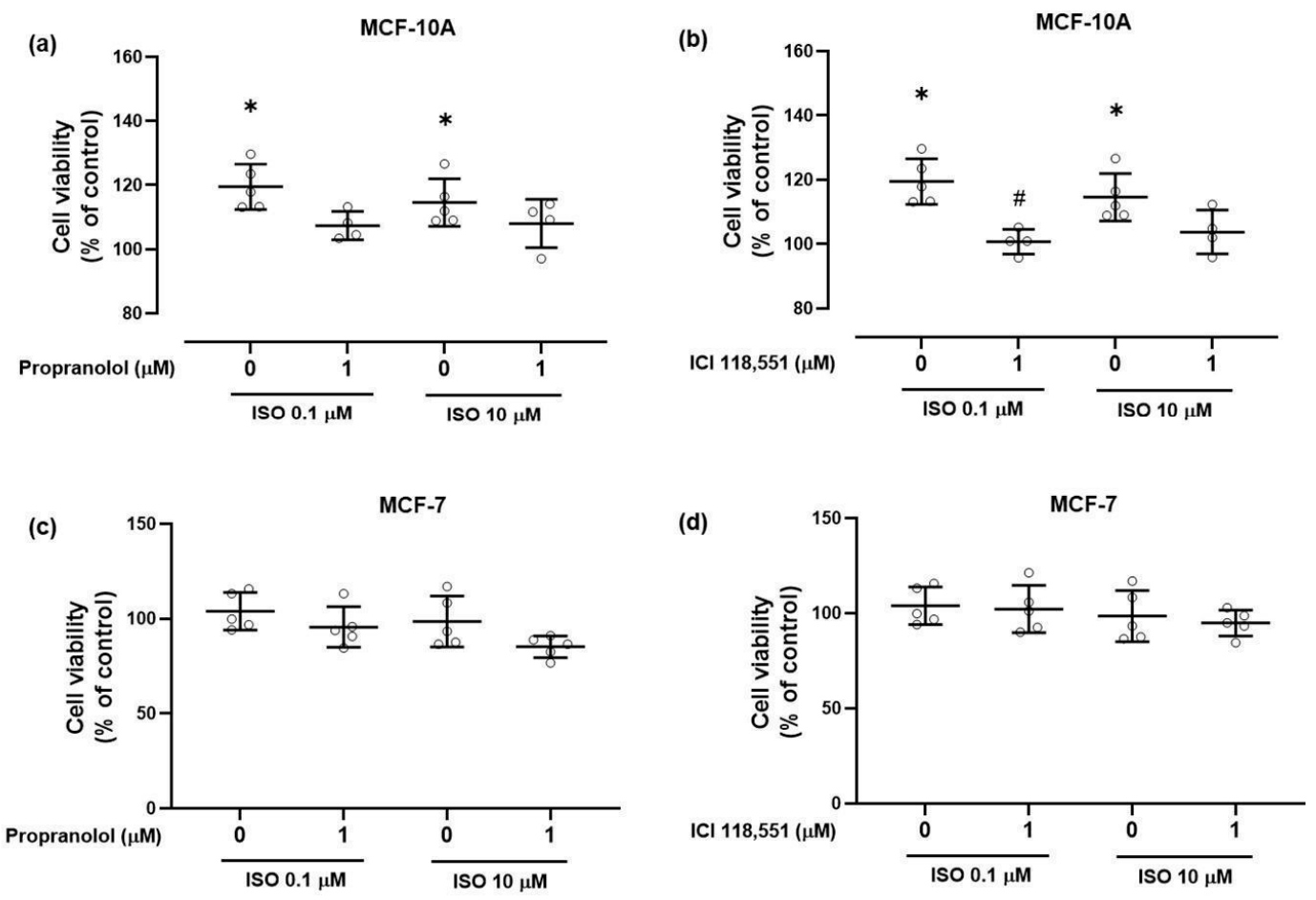

Figure 3. Influence of $\beta$-adrenoceptor agonist, isoprenaline (ISO, 0.1 and $10 \mu \mathrm{M}$ ), alone or in combination with $\beta$-adrenoceptor antagonists, $(\mathbf{a}, \mathbf{c})$ propranolol $(1 \mu \mathrm{M})$ or $(\mathbf{b}, \mathbf{d})$ ICI $118,551(1 \mu \mathrm{M})$ on cell viability of $(\mathbf{a}, \mathbf{b})$ MCF-10A and (c,d) MCF-7 cells, using the MTT assay. Propranolol and ICI 118,551, per se, did not change cell viability in both cell lines tested (see text). Cells were treated with the indicated drugs for $24 \mathrm{~h}$. Results are expressed as percentage of control (solvent) and are presented as mean $\pm \mathrm{SD}$. Values are means \pm SD from 4-5 (MCF-10A cells) or 5 (MCF-7 cells) independent experiments, as shown. Significant differences from control group: * $p \leq 0.05$; one-way analysis of variance (ANOVA), followed by post-hoc multi-comparisons Dunnett's test. Significant differences from isoprenaline treatment: * $p \leq 0.05$; (Student's $t$-test).

In MCF-7 cells, this long exposure (7 days) revealed an ability of isoprenaline to reduce colony formation: isoprenaline $(10 \mu \mathrm{M})$ reduced the number of colonies formed (Figure $4 \mathrm{c}$ ) whereas propranolol or ICI 118,551 $(1 \mu \mathrm{M})$, per se, did not change the clonogenic ability of MCF-7 cells. When combined with isoprenaline $(10 \mu \mathrm{M})$, neither propranolol nor ICI 118,551 were able to antagonise the effect of the $\beta$-adrenoceptor agonist isoprenaline. Images of a representative experiment are shown in Figure 4a.

\subsubsection{Catecholamine Biosynthetic Capacity}

As shown in the assays described above, MCF-7 cells have an ability to synthesize adrenaline greater than that of MCF-10A cells. In order to investigate whether exposure to a $\beta$-adrenoceptor agonist could alter the ability of MCF-10A cells to synthesize adrenaline, MCF-10A cells were exposed to $0.1 \mu \mathrm{M}$ isoprenaline and catecholamines presented in the conditioned medium were quantified. Contrasting with the profile described previously (Table 1), in these experimental conditions, noradrenaline was no longer detected in the conditioned medium of MCF-10A cells, whereas the concentration of adrenaline doubled (from $1.65 \pm 0.29 \mathrm{nM}$ to $3.32 \pm 0.41 \mathrm{nM} ; n=5 ; p \leq 0.05$ ), presenting an adrenaline/noradrenaline ratio closer to that of the tumorigenic MCF-7 cells. In MCF-7 cells, $0.1 \mu \mathrm{M}$ isoprenaline doubled the concentration of noradrenaline in the conditioned medium (from $1.89 \pm 0.51 \mathrm{nM}$ to $3.97 \pm 0.98 \mathrm{nM}$; 
$n=5 ; p \leq 0.05$ ) but reduced, about $75 \%$, the concentration of adrenaline (from $11.02 \pm 1.05 \mathrm{nM}$ to $2.77 \pm 1.33 \mathrm{nM} ; n=5 ; p \leq 0.05)$.

(a)

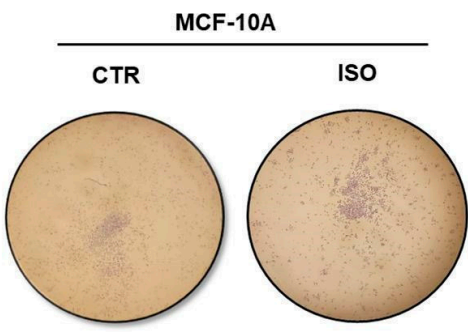

(b)

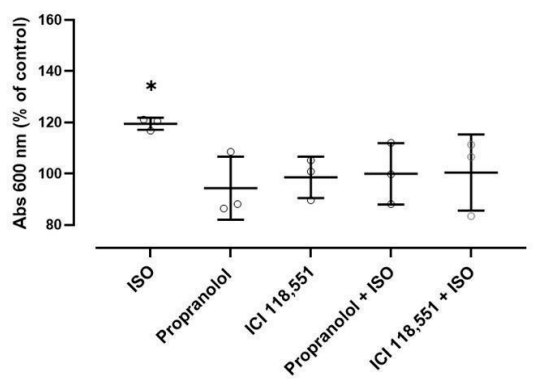

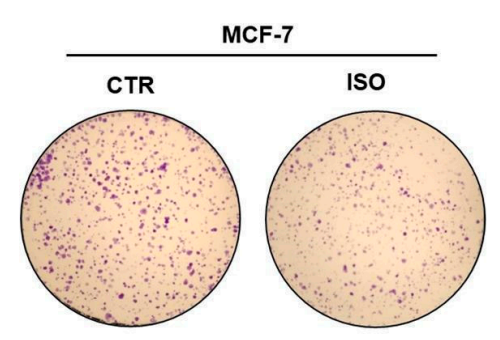

(c)

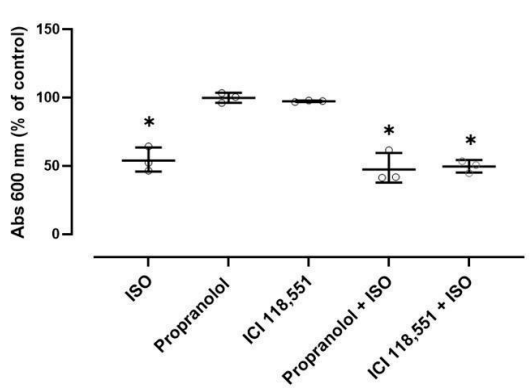

Figure 4. Influence of $\beta$-adrenoceptor agonist, $10 \mu \mathrm{M}$ isoprenaline (ISO), alone or in combination with $\beta$-adrenoceptor antagonists, propranolol or ICI 118,551 (1 $\mu \mathrm{M})$, in MCF-10A and in MCF-7 cells clonogenic ability. Cells were treated with the indicated drugs for seven days. (a) Representative images of the colony formation assay in MCF-10A and in MCF-7 cells in the absence or in the presence of isoprenaline $(10 \mu \mathrm{M})$. (b) Results for absorbance $(\lambda=600 \mathrm{~nm}$ : Abs $600 \mathrm{~nm})$, after crystal violet elution in MCF-10A cells. (c) Results for absorbance $(\lambda=600 \mathrm{~nm}$ : Abs $600 \mathrm{~nm}$ ), after crystal violet elution in MCF-7 cells. Results are expressed as a percentage of control (solvent) and are presented as mean \pm SD, from 3 independent experiments. Significant differences from control group: ${ }^{*} p \leq 0.05$; one-way analysis of variance (ANOVA), followed by post-hoc multi-comparisons Dunnett's test.

\section{Discussion}

The catecholamines noradrenaline and adrenaline are the endogenous ligands of adrenoceptors. They participate in cellular communication, with a well-known role in the neuroendocrine stress-related fight or flight response triggered by the SNS. Therefore, responses mediated by these catecholamines (including in tumorigenesis $[32,33,38]$ have been solely associated with the activation of the SNS. The present study shows that breast cells can also synthesize catecholamines, confirming previous observations in normal human mammary epithelial cells [35], and in non-tumorigenic and tumorigenic breast cell lines $[35,36]$.

Noradrenaline and adrenaline are sequentially synthesized from tyrosine, and the conversion of tyrosine to L-DOPA, catalyzed by $\mathrm{TH}$, is considered the rate-limiting step of catecholamine synthesis $[39,40]$. TH detection has been used to identify cells that synthesize catecholamines and the levels of $\mathrm{TH}$ expression as a way to estimate the potential of a given cell to produce catecholamines [35,36,41]. The present study shows that TH is expressed both in MCF-10A and MCF-7 breast cell lines. However, TH expression in tumorigenic MCF-7 cells is much higher than that observed in non-tumorigenic MCF-10A cells, suggesting that TH expression levels may be linked to the cells' tumorigenic profile.

The TH gene has been previously reported to be a HIF regulated gene [42]. HIF- $1 \alpha$ and HIF-2 $\alpha$ activation induce the expression of genes that are under the control of the hypoxia-responsive element [43]. Tumorigenesis may be associated with a cellular response similar to that occurring when 
cells are exposed to hypoxia (pseudohypoxia). The higher expression level of TH in the tumorigenic cell line (MCF-7), observed in the present study, could be a consequence of the tumorigenic process activated by pseudohypoxia [44]. HIFs may also induce expression of DOPA decarboxylase [45], dopamine $\beta$-hydroxylase [46], and PNMT [47] enzymes which may explain the higher ability of the tumorigenic cells to synthesize catecholamines, in particular, adrenaline.

In the present study, it is shown that relevant enzymes of the catecholamine biosynthetic pathway are expressed and are active in breast MCF-10A and MCF-7 cells, indicating that catecholamines can be produced in an autocrine way, by non-neuronal breast cells, as revealed by i) the detection of catecholamines in the conditioned media of both cell lines and by ii) their capacity to metabolize $\alpha$-methylDOPA to $\alpha$-methylnoradrenaline, an approach previously used in other experimental models and in vivo [48]. Therefore, the described adrenergic effects on breast cancer [49-51] should take into consideration sources of noradrenaline and adrenaline other than the neuroendocrine-released catecholamines.

In non-tumorigenic human breast cells, the main catecholamine produced was reported to be noradrenaline [35]. In the present study, in the tumorigenic MCF-7 cells, adrenaline was the main catecholamine detected in the conditioned medium, suggesting that the adrenaline/noradrenaline ratio may be seen as an index of tumorigenicity. The finding that the adrenaline/noradrenaline ratio observed in the conditioned medium of non-tumorigenic MCF-10A cells was lower than that of MCF-7 cells would fit on such a hypothesis. Interestingly, in MCF-10A cells, activation of $\beta$-adrenoceptor caused an increase of the adrenaline/noradrenaline ratio to a profile similar to that observed in the tumorigenic MCF-7 cells. $\beta_{2}$ - and $\alpha_{2 C}$-adrenoceptors are among the adrenoceptors more often referred to be involved in tumorigenesis and affinity of adrenaline for these receptor subtypes is higher than that of noradrenaline [17] which suggests that adrenaline may be more efficient in activating pathways involved in tumorigenesis.

The observations that, in tumorigenic breast MCF-7 cells, the $\beta$-adrenoceptor agonist isoprenaline reduces cell viability, the clonogenic ability and production of adrenaline is puzzling and seems to contradict the hypothesis that $\beta$-adrenoceptor activation promotes tumorigenesis. Nevertheless, the observation that high concentrations of $\beta$-adrenoceptor antagonists reduce cell viability, similarly to the $\beta$-adrenoceptor agonist isoprenaline, may indicate that $\beta$-adrenoceptors could be already activated by the endogenous ligand (adrenaline) and that exposure to the exogenous agonist might be causing a desensitization of $\beta$-adrenoceptors. Furthermore, $\alpha_{2}$-adrenoceptors are highly expressed in MCF-7 cells [21,52] and yohimbine, a selective $\alpha_{2}$-adrenoceptor antagonist $[53,54]$ also reduced the viability of tumorigenic MCF-7 cells, indicating that $\alpha_{2^{-}}$, like $\beta$-adrenoceptors, are also being activated by locally produced adrenaline. This hypothesis is in line with the established model of drug interaction with G-protein coupled receptors [55] and, at present, seems to be the most likely to explain why agonists and antagonists of the same receptor type are causing the same response in the same cell model. This hypothesis must be challenged in future studies as it may also contribute to explain the controversy around the role of adrenoceptors in the proliferation of cancer breast cell lines [26,52], and to understand why adrenoceptor agonists could exert their effects in concentrations that are three to four orders of magnitude lower [56] than the commonly accepted $\mathrm{EC}_{50}$ values [17].

Several epidemiological studies have shown that propranolol may be particularly effective in reducing the incidence and mortality of different types of cancers, namely breast cancer [57-59]. It is biologically plausible that propranolol exerts this effect not only by blocking the $\beta$-adrenoceptor-mediated tonic activation of tumorigenic cells by the adrenaline autocrinally produced but also by reducing the conditions that favor the acquisition of a tumorigenic phenotype by non-tumorigenic cells. These mechanisms would explain its activity both in metastatic [60] and early-stage breast cancer [61].

Plasma catecholamines levels increase during stressful events [62,63] but also in other physiological conditions such as perimenopause. During perimenopause, there is an increase in catecholamines plasmatic levels, and catecholamines can trigger some of these symptoms, particularly the hot 
flashes [5,64]. Therefore, during perimenopause women will be exposed to increased plasma catecholamines, which, in this respect, is a situation similar to life stressful events. An adrenergic contribution to tumorigenesis would explain why, in the same age interval (45-54 years), breast cancer risk is higher in perimenopausal comparatively to postmenopausal women [65], as exposure to plasma catecholamines fades away during the transition from perimenopause to postmenopause, as evidenced by the disappearance of hot flash events [5].

Considering the results presented, the connection between adrenergic stimulation and tumorigenesis may be more complex than a simple immediate consequence of an increase in plasma catecholamines. It may begin by a transitory effect on breast cells of plasma catecholamines released during a stressful event (step 1), which may lead to the acquisition of tumorigenic potential by predisposed cells (step 2); and by the acquisition, by the altered breast cells, of the ability to produce more adrenaline (step 3), and this autocrine and paracrine adrenaline signaling would contribute to the spread of the adrenergic tumorigenic stimuli to the cells that surround the initial cancerous niche and to cancer progression, regardless of plasma adrenaline levels (step 4), as recently shown [66].

\section{Materials and Methods}

\subsection{Drugs and Antibodies}

(-)-Adrenaline bitartrate, (-)-isoprenaline hydrochloride, prazosin hydrochloride, yohimbine hydrochloride, $( \pm)$-propranolol, $\alpha$-methylDOPA, Dulbecco's Modified Eagle's Medium/F-12 supplemented with $\mathrm{NaHCO}_{3}$, Dulbecco's Modified Eagle's Medium with $\mathrm{NaHCO}_{3}$ and stable L-glutamine, epidermal growth factor, human insulin, hydrocortisone, ICI 118,551, penicillin/streptomycin and HPLC-ECD standards from the highest purity available, were from Sigma-Aldrich (Sintra, Portugal). ITaq ${ }^{\text {TM }}$ Universal SYBR Green supermix was from Biorad (Amadora, Portugal). Foetal bovine serum was from Biochrom and L-glutamine was from Gibco (Biotecnómica, São Mamede, Portugal).

Goat anti-mouse IgG conjugated with Alexa Fluor 488 (a11029) and mouse monoclonal anti-phenylethanolamine N-methyltransferase (MA5-25530) were from Thermo Fisher Scientific (Loures, Portugal). Rabbit polyclonal anti- $\beta_{2}$-adrenoceptor (13096-1-AP) was from Proteintech (Rosemont, IL, USA). Goat anti-rabbit IgG conjugated with Alexa Fluor 594 (ab150092) and rabbit monoclonal anti-tyrosine hydroxylase (ab137869) were purchased from Abcam (Cambridge, UK). Goat anti-rabbit IgG conjugated with horseradish peroxidase (sc-2004) was from Santa Cruz Biotechnology Inc. (Frilabo, Maia, Portugal).

\subsection{Cells and Culture Conditions}

MCF-10A breast human cells (ATCC number CRL-10317 and batch number 64066742/13-12-2017) were purchased from LGC Standards (Barcelona, Spain). MCF-7 breast human cancer cells (ECACC 86012803/25-10-2017) were purchased from Sigma-Aldrich/Merck (Sintra, Portugal). MCF-7 cells were cultured in Dulbecco's modified Eagle medium (DMEM) containing $3.7 \mathrm{~g} / \mathrm{L} \mathrm{NaHCO} 3$ and stable glutamine, supplemented with $100 \mathrm{U} / \mathrm{mL}$ penicillin and $100 \mu \mathrm{g} / \mathrm{mL}$ streptomycin and $10 \%$ heat-inactivated foetal bovine serum (FBS). MCF-10A cells were cultured in medium DMEM/F12 containing the same supplements listed for MCF-7 cells plus $3.5 \mu \mathrm{g} / \mathrm{mL}$ human insulin, $20 \mathrm{ng} / \mathrm{mL}$ epidermal growth factor and $0.5 \mu \mathrm{g} / \mathrm{mL}$ hydrocortisone. MCF-7 and MCF-10A cells were cultured in $75 \mathrm{~cm}^{2}$ culture flasks, at $37^{\circ} \mathrm{C}$ in a humidified atmosphere of $95 \%$ air and $5 \% \mathrm{CO}_{2}$. For cell culture maintenance, cells were routinely subcultured twice a week, treating them with $0.25 \%$ trypsin $/ 0.025 \%$ EDTA, and kept below $90 \%$ confluence. Cells were periodically checked for mycoplasma contamination.

Prior to each experiment, MCF-7 and MCF-10A cells were trypsinized and centrifuged at $457 \times g$ for five minutes at $20^{\circ} \mathrm{C}$. Viable cells, counted using trypan blue dye exclusion method, were seeded at optimized cells densities for different assays. 


\section{3. $m R N A$ Expression by RT-qPCR}

MCF-7 and MCF-10A cells were seeded in Petri dishes of $60.1 \mathrm{~cm}^{2}$, at initial density of $1.0 \times 10^{5}$ and $2.0 \times 10^{5}$ cells $/ \mathrm{mL}$, respectively, and incubated overnight for cell attachment. The RNeasy Mini Kit (Qiagen) was used to extract RNA, according to manufacturer's recommendations. RNA quantification and purity were evaluated with a Synergy HT spectrophotometer (Biotek Instruments Inc., Winooski, VT, USA). As a template, $1500 \mathrm{ng}$ of RNA per sample was used in the Xpert cDNA Synthesis Mastermix kit (Grisp) for reverse-transcriptase reactions. Primers design (Table S1) was accomplished with Beacon Designer Software 7 (PREMIER Biosoft). Prior to use, NCBI BLAST analysis was used to confirm primer specificity. Following PCR, primer specificity was further checked by confirming that the dissociation curve had one single peak, with an observed Tm (primer melting temperature) consistent with the amplicon length. The relative efficiency and quality of primers was evaluated using standard dilutions of cDNA.

For qPCR amplifications, $5 \mu \mathrm{L}$ of $2 \times$ iTaq $^{\text {TM }}$ Universal SYBR Green Supermix, $0.25 \mu \mathrm{M}$ of each primer and $1 \mu \mathrm{L}$ of template cDNA were used. In all qPCR experiments, amplifications were performed in duplicate and negative controls (no template cDNA) were included. The CFX384 Touch ${ }^{\mathrm{TM}}$ Real-Time PCR Detection System (Bio-Rad, Hercules, CA, United States) was used to perform qPCRs experiments. Conditions were as follows: $95^{\circ} \mathrm{C}$ for $3 \mathrm{~min}, 40$ cycles of denaturation at $95{ }^{\circ} \mathrm{C}$ for $10 \mathrm{~s}$ and $60{ }^{\circ} \mathrm{C}$ annealing temperature for $30 \mathrm{~s}$. Melting curves of the PCR amplicons were made with temperatures ranging from $55{ }^{\circ} \mathrm{C}$ to $95^{\circ} \mathrm{C}$, with increments of $0.5^{\circ} \mathrm{C}$ at a rate of $10 \mathrm{~s} / \mathrm{step}$. CFX Manager ${ }^{\mathrm{TM}} 2.0$ (Bio-Rad) was used to analyze the melting curve data. The data obtained were analyzed using the method described by Pfaffl [67]. For normalization purposes, GAPDH and $\beta$-actin were used as reference genes in each analysis.

\subsection{Western Blot}

MCF-7 and MCF-10A cells were seeded in Petri dishes of $60.1 \mathrm{~cm}^{2}$, at an initial density of $1.0 \times 10^{5}$ and $2.0 \times 10^{5}$ cells $/ \mathrm{mL}$, respectively, and incubated overnight for cell attachment.

After gently washing cells ice-cold PBS, total protein extraction was accomplished in lysis buffer with protease inhibitors $\left(1 \mathrm{mM} \mathrm{Na} \mathrm{VO}_{4}, 1 \mathrm{mM} \mathrm{NaF}, 1 \mathrm{mM} \mathrm{PMSF}, 2 \mu \mathrm{g} / \mathrm{mL}\right.$ aprotinin and $2 \mu \mathrm{g} / \mathrm{mL}$ leupeptin). Samples were, then, homogenized with two cycles of $15 \mathrm{~s}$ at $5800 \mathrm{rpm}$ in the Precellys Evolution Homogenizer (Bertin Instruments, Montigny le Bretonneux, France) to ensure total cell disruption, followed by an incubation period of $1 \mathrm{~h}$ on ice for $1 \mathrm{~h}$ and a centrifugation at $20,000 \times g$ for $45 \min$ at $4{ }^{\circ} \mathrm{C}$.

Total protein concentration in the supernatant was determined using the Bradford method, using bovine-albumin as standard. Afterwards, equal amounts of protein $(50 \mu \mathrm{g})$ were heat-denatured through boiling at $70{ }^{\circ} \mathrm{C}$ for $10 \mathrm{~min}$ in $6 \times$ sample buffer $[0.35 \mathrm{M}$ Tris- $\mathrm{HCl}$ at $\mathrm{pH} 6.8,10 \%$ sodium dodecyl sulfate (SDS), 30\% glycerol, $9.3 \%$ dithiothreitol and $0.01 \%$ bromophenol blue]. Proteins were subjected to 10\% SDS-PAGE (SDS-polyacrylamide gel electrophoresis) and transferred from gels onto pure nitrocellulose membranes at $25 \mathrm{~V}$ and $2.5 \mathrm{~A}$, for $3 \mathrm{~min}$ using the Trans-Blot Turbo Transfer System (Bio-Rad). Membranes were blocked for $1 \mathrm{~h}$ at room temperature with 5\% BSA in PBST $(0.1 \%$ Tween 20 in PBS pH 7.4) and then probed overnight at $4{ }^{\circ} \mathrm{C}$ with primary antibody rabbit anti- $\beta_{2}$-adrenoceptor (1:500) followed by secondary antibody goat anti-rabbit IgG conjugated to horseradish peroxidase (1:5000). Stain-free total protein staining was used as a loading control. Immunocomplexes were detected by an enhanced chemiluminescence system (Novex ECL, Life Technologies, Carlsbad, CA, USA) and imaged using a ChemiDoc MP Imaging System (Bio-Rad).

\subsection{Immunocytochemistry Assay}

MCF-7 and MCF-10A cells were seeded in 96-well plates, at an initial density of $1.5 \times 10^{4}$ and $2.0 \times 10^{4}$ cells $/ \mathrm{mL}$, respectively. After 24 -h incubation, cells were fixed with $4 \%$ paraformaldehyde and $4 \%$ sucrose in PBS for $10 \mathrm{~min}$. Nonspecific binding sites were blocked by incubating cells with a 
solution containing $10 \%$ FBS, $1 \%$ bovine serum albumin, $0.1 \%$ Triton $\mathrm{X}, 0.05 \% \mathrm{NaN}_{3}$ in PBS, for $1 \mathrm{~h}$. Cells were then incubated overnight at $4{ }^{\circ} \mathrm{C}$, in a humidified atmosphere, with the following primary antibodies: rabbit anti-TH (1:150), mouse anti-PNMT (1:400) and rabbit anti- $\beta_{2}$-adrenoceptor (1:100). Primary antibodies were diluted in PBS containing 5\% FBS, $1 \%$ bovine serum albumin, $0.1 \%$ Triton $X$, $0.05 \% \mathrm{NaN}_{3}$. Afterwards, cells were incubated for $1 \mathrm{~h}$, at room temperature, with either the secondary antibodies goat anti-rabbit IgG conjugated to Alexa Fluor 594 (1:1000, for TH and $\beta_{2}$-adrenoceptors) or the goat anti-mouse IgG conjugated to Alexa Fluor 488 (1:400, for PNMT). In negative controls, the primary antibody was omitted. Cell nuclei were labelled with Hoechst $33342(5 \mu \mathrm{g} / \mathrm{mL})$ for $1 \mathrm{~min}$ at room temperature. Images were captured with the Lionheart FX Automated Microscope (Biotek Instruments Inc.).

\subsection{HPLC-ECD Analysis}

MCF-7 and MCF-10A cells were seeded in 24-well plates at an initial density of $3.4 \times 10^{4}$ and $1.0 \times 10^{5}$ cells $/ \mathrm{mL}$, respectively and incubated for $24 \mathrm{~h}$ for cell attachment.

To screen for the presence of endogenous catecholamines, experiments were performed in the absence of FBS in order to avoid interferences from serum catecholamines, as described by Dibner and Insel [68]. Briefly, after 24-h of incubation in serum-free media, supernatants and cells were separated into distinct fractions and acidified with $2 \mathrm{M}$ perchloric acid (1:10). The samples were filtered, centrifuged and frozen $\left(-20^{\circ} \mathrm{C}\right)$ until analysis. Catecholamines (dopamine, noradrenaline, adrenaline, $\alpha$-methylnoradrenaline) and $\alpha$-methylDOPA were determined by HPLC-ECD using the 3030 Reagent $\mathrm{kit}^{\circledR}$ for HPLC analysis of catecholamines in urine according to the instructions of the manufacturer (Chromsystems GmbH, Munich, Germany). The HPLC system used was a Waters Alliance 2695 pump (Waters Corporation, Milford, MA, USA) with a Rheodyne loop injector and a Decade (Antec Scientific, Netherlands) electrochemical detector (ECD) with a glassy carbon electrode set to a potential of $+0.75 \mathrm{~V}$ and $+0.50 \mathrm{~V}$, respectively. Empower Pro (Waters Corporation, USA) software was used to monitor the current produced. The concentrations used for the calibration curve range between 1.0 to $1000 \mathrm{nM}$ (in $\mathrm{HCl} 0.1 \mathrm{M}$ ) for all chemical entities tested. The concentration of catecholamines presented in each sample was calculated using the calibration curve, according to the manufacturer manual.

\subsection{Cell Viability Assay}

Cell viability assays were performed using the MTT (3-(4,5-dimethylthiazol-2-yl)2,5-diphenyltetrazolium bromide) tetrazolium reduction assay, as previously described [69]. MCF-7 and MCF-10A cells were seeded in 96-well plates, at an initial density of $2.3 \times 10^{4}$ or $4.0 \times 10^{4}$ cells $/ \mathrm{mL}$, respectively, and allowed to attach for $24 \mathrm{~h}$.

To study the effect of drugs in cell viability, FBS concentration in the medium was reduced in both cell lines considering both cell viability and minor FBS interference in cell proliferation. As such, MCF-10A and MCF-7 cells were incubated with drugs in culture medium containing either $4 \%$ or $0 \%$ FBS, respectively. Both cell lines were incubated with adrenaline $(0.1,1,10 \mu \mathrm{M})$, isoprenaline $(0.1$, $10 \mu \mathrm{M})$, prazosin $(1 \mu \mathrm{M})$, propranolol $(1,10 \mu \mathrm{M})$, ICI 118,551 $(1 \mu \mathrm{M})$ and yohimbine $(1 \mu \mathrm{M})$, alone or in combination, in parallel with the respective control (solvent), for 24 or $72 \mathrm{~h}$. After drug treatment, the cell culture medium was removed and the MTT reagent $(0.5 \mathrm{mg} / \mathrm{mL}$ in PBS; $100 \mu \mathrm{L})$ was added to each well, followed by an incubation period of three hours, protected from light. After this period, the MTT solution was removed to dissolve the formazan crystals formed and $100 \mu \mathrm{L}$ dimethylsulfoxide was added to each well. Absorbance at $570 \mathrm{~nm}$ was determined in an automated microplate reader (Synergy HT, Biotek Instruments Inc.). Results were expressed as a percentage of control (non-treated). All conditions were performed in parallel triplicates or sextuplicates.

\subsection{Colony Formation Assay}

The colony formation ability was assessed using the clonogenic assay of cells in vitro [70], adapted as described previously [71]. Briefly, MCF-7 and MCF-10A cells were seeded at an initial density of 
1000 cells/well, in 6-well or in 12-well plates, respectively, and allowed to attach for $24 \mathrm{~h}$. Thereafter, cells were incubated with isoprenaline $(10 \mu \mathrm{M})$, propranolol $(1 \mu \mathrm{M})$, and ICI 118,551 $(1 \mu \mathrm{M})$, alone or in combination, in parallel with the respective solvent (control), for 7 days. During this period, drugs were renewed after a $72 \mathrm{~h}$ incubation period.

At the end of the experiment, colonies were fixed with $4 \%$ paraformaldehyde in PBS for $5 \mathrm{~min}$, stained with $0.5 \%$ crystal violet for $5 \mathrm{~min}$ and finally rinsed twice with distilled water. Representative images of the colonies were taken using a digital camera. Quantitative changes in the clonogenic ability were determined by extracting colonies with $10 \%$ acetic acid and measuring the absorbance at $600 \mathrm{~nm}$ in an automated microplate reader (Synergy HT, Biotek Instruments Inc.), since a correlation between the number of colonies formed and the absorbance of the extracted dye, using ImageJ software, was achieved (data not shown). All conditions were performed in parallel, in duplicates or triplicates.

\subsection{Statistical Analysis}

The study was designed as an exploratory study. It was assumed that 5 independent experiments would be sufficient to detect statistically significant differences in cell viability assays. In the other assays (RT-PCR, HPLC-ECD and colony formation) a minimum of 3 independent experiments were considered for the statistical evaluation. GraphPad Prism 8 software was used to design graphs and perform statistical analysis. Differences between treatments and controls were compared using one-way analysis of variance (ANOVA), followed by the post-hoc multiple comparisons Dunnett's test, whenever applicable, or using a Student's $t$-test, otherwise.

\section{Conclusions}

Breast cancer cells, at least those with characteristics similar to the MCF-7 cells, have the capacity to synthesize and release adrenaline. Such capacity to release adrenaline may be triggered by exposure of non-tumorigenic cells to a $\beta$-adrenoceptor agonist. Taken together, the present results bring a new perspective to understand the increase in breast cancer incidence caused by stress and during perimenopause (a period where peaks of plasma catecholamines occur) and to interpret the claimed protective effect of propranolol and similar $\beta$-blockers in breast cancer.

Supplementary Materials: Supplementary materials can be found at http://www.mdpi.com/1422-0067/21/21/ 7968/s1.

Author Contributions: Conceptualization: J.G., P.F., N.V.; Methodology: C.Q., D.S., F.A., N.V., H.R., J.C.O., P.F.; Formal analysis and investigation: D.S., F.A., H.R., C.Q., J.C.O., P.F., N.V.; Writing-original draft preparation: D.S., F.A., J.G., P.F.; Writing-review and editing: F.A., D.S., H.R., J.C.O., C.Q., N.V., J.G., P.F.; Funding acquisition: J.G.; Resources: J.G., J.C.O., N.V.; Supervision: J.G., N.V., P.F. All authors have read and agreed to the published version of the manuscript.

Funding: The research work of the group was supported by Infosaúde, from the National Association of Pharmacies (ANF), project Drug Repurposing 2020, according to the principles of scientific independence applicable to scientific patronage.

Conflicts of Interest: The authors declare no conflict of interest. The funders had no role in the design of the study; in the collection, analyses, or interpretation of data; in the writing of the manuscript, or in the decision to publish the results.

\section{Abbreviations}

DMEM Dulbecco's Modified Eagle Medium

FBS Foetal bovine serum

ISO Isoprenaline

MTT 3-(4,5-dimethylthiazol-2-yl)-2,5-diphenyltetrazolium bromide

PNMT Phenylethanolamine N-methyltransferase

SDS Sodium dodecyl sulfate

SNS Sympathetic nervous system

TH Tyrosine hydroxylase

$\beta_{2}$-AR $\quad \beta_{2}$-adrenoceptors 


\section{References}

1. Holmes, T.H.; Rahe, R.H. The social readjustment rating scale. J. Psychosom. Res. 1967, 11, 213-218. [CrossRef]

2. Kruk, J.; Aboul-Enein, B.H.; Bernstein, J.; Gronostaj, M. Psychological Stress and Cellular Aging in Cancer: A Meta-Analysis. Oxidative Med. Cell. Longev. 2019, 2019, 1-23. [CrossRef] [PubMed]

3. Chida, Y.; Hamer, M.; Wardle, J.; Steptoe, A. Do stress-related psychosocial factors contribute to cancer incidence and survival? Nat. Clin. Pr. Oncol. 2008, 5, 466-475. [CrossRef] [PubMed]

4. Paran, E.; Neumann, L.; Cristal, N. Effects of mental and physical stress on plasma catecholamine levels before and after $\beta$-adrenoceptor blocker treatment. Eur. J. Clin. Pharmacol. 1992, 43, 11-15. [CrossRef]

5. Kronenberg, F.; Côte, L.J.; Linkie, D.M.; Dyrenfurth, I.; Downey, J.A. Menopausal hot flashes: Thermoregulatory, cardiovascular, and circulating catecholamine and LH changes. Maturitas 1984, 6, 31-43. [CrossRef]

6. Cignarelli, M.; Cicinelli, E.; Corso, M.; Cospite, M.; Garruti, G.; Tafaro, E.; Giorgino, R.; Schonauer, S. Biophysical and Endocrine-Metabolic Changes during Menopausal Hot Flashes: Increase in Plasma Free Fatty Acid and Norepinephrine Levels. Gynecol. Obstet. Investig. 1989, 27, 34-37. [CrossRef] [PubMed]

7. Thaker, P.H.; Lutgendorf, S.K.; Sood, A.K. The Neuroendocrine Impact of Chronic Stress on Cancer. Cell Cycle 2007, 6, 430-433. [CrossRef] [PubMed]

8. Qiao, G.; Chen, M.; Bucsek, M.J.; Repasky, E.A.; Hylander, B.L. Adrenergic Signaling: A Targetable Checkpoint Limiting Development of the Antitumor Immune Response. Front. Immunol. 2018, 9, 164. [CrossRef]

9. Monte, M.D.; Calvani, M.; Cammalleri, M.; Favre, C.; Filippi, L.; Bagnoli, P. $\beta$-Adrenoceptors as drug targets in melanoma: Novel preclinical evidence for a role of $\beta 3$-adrenoceptors. Br. J. Pharmacol. 2018, 176, 2496-2508. [CrossRef]

10. Ritchie, A.C. The Effect of Local Injections of Adrenalin on Epidermal Carcinogenesis in the Mouse. J. Natl. Cancer Inst. 1952, 12, 839-846. [CrossRef]

11. Coelho, M.; Moz, M.; Correia, G.; Teixeira, A.; Medeiros, R.; Ribeiro, L. Antiproliferative effects of $\beta$-blockers on human colorectal cancer cells. Oncol. Rep. 2015, 33, 2513-2520. [CrossRef] [PubMed]

12. Lin, Q.; Wang, F.; Yang, R.; Zheng, X.; Gao, H.; Zhang, P. Effect of Chronic Restraint Stress on Human Colorectal Carcinoma Growth in Mice. PLoS ONE 2013, 8, e61435. [CrossRef]

13. Masur, K.; Niggemann, B.; Zanker, K.S.; Entschladen, F. Norepinephrine-induced migration of SW 480 colon carcinoma cells is inhibited by beta-blockers. Cancer Res. 2001, 61, 2866-2869. [PubMed]

14. Yang, E.V.; Sood, A.K.; Chen, M.; Li, Y.; Eubank, T.D.; Marsh, C.B.; Jewell, S.; Flavahan, N.A.; Morrison, C.; Yeh, P.-E.; et al. Norepinephrine Up-regulates the Expression of Vascular Endothelial Growth Factor, Matrix Metalloproteinase (MMP)-2, and MMP-9 in Nasopharyngeal Carcinoma Tumor Cells. Cancer Res. 2006, 66, 10357-10364. [CrossRef]

15. Barbieri, A.; Bimonte, S.; De Palma, G.; Luciano, A.; Rea, D.; Giudice, A.; Scognamiglio, G.; La Mantia, E.; Franco, R.; Perdonà, S.; et al. The stress hormone norepinephrine increases migration of prostate cancer cells in vitro and in vivo. Int. J. Oncol. 2015, 47, 527-534. [CrossRef] [PubMed]

16. Ma, Q.; Guo, K.; Wang, L.; Hu, H.; Li, J.; Zhang, D.; Zhang, M. Norepinephrine-induced invasion by pancreatic cancer cells is inhibited by propranolol. Oncol. Rep. 2009, 22, 825-830. [CrossRef]

17. Altosaar, K.; Balaji, P.; Bond, R.A.; Bylund, D.B.; Cotecchia, S.; Devost, D.; Doze, V.A.; Eikenburg, D.C.; Gora, S.; Goupil, E.; et al. Adrenoceptors (version 2019.4) in the IUPHAR/BPS Guide to Pharmacology Database. IUPHAR/BPS Guid. Pharmacol. CITE 2019, 2019. [CrossRef]

18. Lüthy, I.A.; Bruzzone, A.; Piñero, C.P.; Castillo, L.; Chiesa, I.; Vázquez, S.; Sarappa, M. Adrenoceptors: Non Conventional Target for Breast Cancer? Curr. Med. Chem. 2009, 16, 1850-1862. [CrossRef]

19. Iishi, H.; Tatsuta, M.; Baba, M.; Sakai, N.; Yano, H.; Uehara, H.; Nakaizumi, A.; Iseki, K. Promotion by the $\alpha$-adrenoceptor agonist phenylephrine, but not by the $\beta$-adrenoceptor agonist isoproterenol, of gastric carcinogenesis induced by N-methyl-N'-nitro-N-nitrosoguanidine in Wistar rats. Cancer Lett. 1998, 122, 61-65. [CrossRef]

20. Kyprianou, N.; Benning, C.M. Suppression of human prostate cancer cell growth by alpha1-adrenoceptor antagonists doxazosin and terazosin via induction of apoptosis. Cancer Res. 2000, 60, 4550-4555.

21. Vázquez, S.M.; Mladovan, A.G.; Pérez, C.; Bruzzone, A.; Baldi, A.; Lüthy, I.A. Human breast cell lines exhibit functional $\alpha 2$-adrenoceptors. Cancer Chemother. Pharmacol. 2005, 58, 50-61. [CrossRef] 
22. Lamkin, D.M.; Sung, H.Y.; Yang, G.S.; David, J.M.; Ma, J.C.; Cole, S.W.; Sloan, E.K. $\alpha 2$-Adrenergic blockade mimics the enhancing effect of chronic stress on breast cancer progression. Psychoneuroendocrinology 2014, 51, 262-270. [CrossRef]

23. Schuller, H.M.; Cole, B. Regulation of cell proliferation by $\beta$-adrenergjc receptors in a human lung adenocarcinoma cell line. Carcinogenesis 1989, 10, 1753-1755. [CrossRef]

24. Yazawa, T.; Kaira, K.; Shimizu, K.; Shimizu, A.; Mori, K.; Nagashima, T.; Ohtaki, Y.; Oyama, T.; Mogi, A.; Kuwano, H. Prognostic significance of beta2-adrenergic receptor expression in non-small cell lung cancer. Am. J. Transl. Res. 2016, 8, 5059-5070. [PubMed]

25. Re, G.; Badino, P.; Novelli, A.; Girardi, C.; Di Carlo, F. Evidence for functional $\beta$-adrenoceptor subtypes in cg-5 breast cancer cells. Pharmacol. Res. 1996, 33, 255-260. [CrossRef]

26. Piñero, C.P.; Bruzzone, A.; Sarappa, M.G.; Castillo, L.F.; Lüthy, I.A. Involvement of $\alpha 2$ - and $\beta 2$-adrenoceptors on breast cancer cell proliferation and tumour growth regulation. Br. J. Pharmacol. 2012, 166, 721-736. [CrossRef]

27. Thaker, P.H.; Han, L.Y.; Kamat, A.A.; Arevalo, J.M.; Takahashi, R.; Lu, C.; Jennings, N.B.; Armaiz-Pena, G.; Bankson, J.A.; Ravoori, M.; et al. Chronic stress promotes tumor growth and angiogenesis in a mouse model of ovarian carcinoma. Nat. Med. 2006, 12, 939-944. [CrossRef] [PubMed]

28. Huang, X.-Y.; Wang, H.-C.; Yuan, Z.; Huang, J.; Zheng, Q. Norepinephrine Stimulates Pancreatic Cancer Cell Proliferation, Migration and Invasion Via ß-Adrenergic Receptor-Dependent Activation of P38/MAPK Pathway. Hepatogastroenterology 2011, 59, 889-893. [CrossRef] [PubMed]

29. Maccari, S.; Buoncervello, M.; Rampin, A.; Spada, M.; Macchia, D.; Giordani, L.; Stati, T.; Bearzi, C.; Catalano, L.; Rizzi, R.; et al. Biphasic effects of propranolol on tumour growth in B16F10 melanoma-bearing mice. Br. J. Pharmacol. 2016, 174, 139-149. [CrossRef]

30. De Giorgi, V.; Grazzini, M.; Benemei, S.; Marchionni, N.; Geppetti, P.; Gandini, S. $\beta$-Blocker use and reduced disease progression in patients with thick melanoma. Melanoma Res. 2017, 27, 268-270. [CrossRef]

31. Zhong, S.; Yu, D.; Zhang, X.; Chen, X.; Yang, S.; Tang, J.; Zhong, S.-L.; Wang, S. $\beta$-Blocker use and mortality in cancer patients. Eur. J. Cancer Prev. 2016, 25, 440-448. [CrossRef] [PubMed]

32. Kamiya, A.; Hayama, Y.; Kato, S.; Shimomura, A.; Shimomura, T.; Irie, K.; Kaneko, R.; Yanagawa, Y.; Kobayashi, K.; Ochiya, T. Genetic manipulation of autonomic nerve fiber innervation and activity and its effect on breast cancer progression. Nat. Neurosci. 2019, 22, 1289-1305. [CrossRef]

33. Zhang, X.; Zhang, Y.; He, Z.; Yin, K.; Li, B.; Zhang, L.; Xu, Z. Chronic stress promotes gastric cancer progression and metastasis: An essential role for ADRB2. Cell Death Dis. 2019, 10, 1-15. [CrossRef] [PubMed]

34. Repasky, E.A.; Eng, J.; Hylander, B.L. Stress, Metabolism and Cancer. Cancer J. 2015, 21, 97-103. [CrossRef]

35. Chiba, T.; Maeda, T.; Fujita, Y.; Takeda, R.; Kikuchi, A.; Kudo, K. Stress-Induced Suppression of Milk Protein Is Involved in a Noradrenergic Mechanism in the Mammary Gland. Endocrinology 2019, 160, 2074-2084. [CrossRef] [PubMed]

36. Shi, M.; Liu, D.; Duan, H.; Qian, L.; Wang, L.; Niu, L.; Zhang, H.; Yong, Z.; Gong, Z.; Song, L.; et al. The $\beta 2$-adrenergic receptor and Her2 comprise a positive feedback loop in human breast cancer cells. Breast Cancer Res. Treat. 2010, 125, 351-362. [CrossRef]

37. Menyhárt, O.; Harami-Papp, H.; Sukumar, S.; Schäfer, R.; Magnani, L.; De Barrios, O.; Győrffy, B. Guidelines for the selection of functional assays to evaluate the hallmarks of cancer. Biochim. Biophys. Acta Bioenerg. 2016, 1866, 300-319. [CrossRef]

38. Obeid, E.I.; Conzen, S.D. The role of adrenergic signaling in breast cancer biology. Cancer Biomark. 2013, 13, 161-169. [CrossRef]

39. Flatmark, T.; Stevens, R.C. Structural Insight into the Aromatic Amino Acid Hydroxylases and Their Disease-Related Mutant Forms. Chem. Rev. 1999, 99, 2137-2160. [CrossRef]

40. Ekobayashi, K.; Nagatsu, T. Molecular genetics of tyrosine 3-monooxygenase and inherited diseases. Biochem. Biophys. Res. Commun. 2005, 338, 267-270. [CrossRef]

41. Flierl, M.A.; Rittirsch, D.; Nadeau, B.A.; Chen, A.J.; Sarma, J.V.; Zetoune, F.S.; McGuire, S.R.; List, R.P.; Day, D.E.; Hoesel, L.M.; et al. Phagocyte-derived catecholamines enhance acute inflammatory injury. Nat. Cell Biol. 2007, 449, 721-725. [CrossRef] [PubMed]

42. Schnell, P.O.; Ignacak, M.L.; Bauer, A.L.; Striet, J.B.; Paulding, W.R.; Czyzyk-Krzeska, M.F. Regulation of tyrosine hydroxylase promoter activity by the von Hippel-Lindau tumor suppressor protein and hypoxia-inducible transcription factors. J. Neurochem. 2003, 85, 483-491. [CrossRef] 
43. Hayashi, Y.; Yokota, A.; Harada, H.; Huang, G. Hypoxia/pseudohypoxia-mediated activation of hypoxia-inducible factor-1 $\alpha$ in cancer. Cancer Sci. 2019, 110, 1510-1517. [CrossRef] [PubMed]

44. Mohlin, S.; Wigerup, C.; Jögi, A.; Påhlman, S. Hypoxia, pseudohypoxia and cellular differentiation. Exp. Cell Res. 2017, 356, 192-196. [CrossRef]

45. Brown, S.T.; Kelly, K.F.; Daniel, J.M.; Nurse, C.A. Hypoxia inducible factor (HIF)-2 $\alpha$ is required for the development of the catecholaminergic phenotype of sympathoadrenal cells. J. Neurochem. 2009, 110, 622-630. [CrossRef]

46. Hui, A.S.; Striet, J.B.; Gudelsky, G.A.; Soukhova, G.K.; Gozal, E.; Beitner-Johnson, D.; Guo, S.-Z.; Sachleben, L.R.; Haycock, J.W.; Gozal, D.; et al. Regulation of Catecholamines by Sustained and Intermittent Hypoxia in Neuroendocrine Cells and Sympathetic Neurons. Hypertension 2003, 42, 1130-1136. [CrossRef]

47. Wong, D.L.; Tai, T.C.; Wong-Faull, D.C.; Claycomb, R.; Siddall, B.J.; Bell, R.A.; Kvetnansky, R. Stress and Adrenergic Function: HIF1 $\alpha$, a Potential Regulatory Switch. Cell. Mol. Neurobiol. 2010, 30, 1451-1457. [CrossRef] [PubMed]

48. Waldmeier, P.; Hedwall, P.R.; Maître, L. On the role of $\alpha$-methyldopamine in the antihypertensive effect of

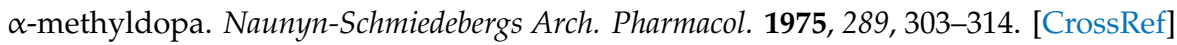

49. Cui, B.; Luo, Y.; Tian, P.; Peng, F.; Lu, J.; Yang, Y.; Su, Q.; Liu, B.; Yu, J.; Luo, X.; et al. Stress-induced epinephrine enhances lactate dehydrogenase A and promotes breast cancer stem-like cells. J. Clin. Investig. 2019, 129, 1030-1046. [CrossRef]

50. Ouyang, X.; Zhu, Z.; Yang, C.; Wang, L.; Ding, G.; Jiang, F. Epinephrine increases malignancy of breast cancer through p38 MAPK signaling pathway in depressive disorders. Int. J. Clin. Exp. Pathol. 2019, 12, 1932-1946.

51. Zhang, Z.; Wang, Y.; Li, Q. Mechanisms underlying the effects of stress on tumorigenesis and metastasis (Review). Int. J. Oncol. 2018, 53, 2332-2342. [CrossRef] [PubMed]

52. Vázquez, S.M.; Pignataro, O.; Luthy, I.A. $\alpha 2$-Adrenergic effect on human breast cancer MCF-7 cells. Breast Cancer Res. Treat. 1999, 55, 41-49. [CrossRef]

53. Starke, K.; Borowski, E.; Endo, T. Preferential blockade of presynaptic $\alpha$-adrenoceptors by yohimbine. Eur. J. Pharmacol. 1975, 34, 385-388. [CrossRef]

54. Bylund, D.B.; Blaxall, H.S.; Iversen, L.J.; Caron, M.G.; Lefkowitz, R.J.; Lomasney, J.W. Pharmacological characteristics of alpha 2-adrenergic receptors: Comparison of pharmacologically defined subtypes with subtypes identified by molecular cloning. Mol. Pharmacol. 1992, 42, 1-5. [PubMed]

55. Kenakin, T. Drug efficacy at G protein-coupledreceptors. Annu. Rev. Pharmacol. Toxicol. 2002, 42, 349-379. [CrossRef] [PubMed]

56. Bruzzone, A.; Saulière, A.; Finana, F.; Sénard, J.; Lüthy, I.; Galés, C. Dosage-dependent regulation of cell proliferation and adhesion through dual $\beta 2$-adrenergic receptor/cAMP signals. FASEB J. 2013, 28, 1342-1354. [CrossRef] [PubMed]

57. Barron, T.I.; Connolly, R.M.; Sharp, L.; Bennett, K.; Visvanathan, K. Beta Blockers and Breast Cancer Mortality: A Population-Based Study. J. Clin. Oncol. 2011, 29, 2635-2644. [CrossRef]

58. Powe, D.G.; Voss, M.J.; Zänker, K.S.; Habashy, H.O.; Green, A.R.; Ellis, I.O.; Entschladen, F. Beta-Blocker Drug Therapy Reduces Secondary Cancer Formation in Breast Cancer and Improves Cancer Specific Survival. Oncotarget 2010, 1, 628-638. [CrossRef]

59. Chang, P.-Y.; Huang, W.-Y.; Lin, C.-L.; Huang, T.-C.; Wu, Y.-Y.; Chen, J.-H.; Kao, C.-H. Propranolol reduces cancer risk: A population-based cohort study. Medicine 2015, 94, e1097. [CrossRef]

60. Choy, C.; Raytis, J.L.; Smith, D.D.; Duenas, M.; Neman, J.; Jandial, R.; Lew, M.W. Inhibition of $\beta 2$-adrenergic receptor reduces triple-negative breast cancer brain metastases: The potential benefit of perioperative $\beta$-blockade. Oncol. Rep. 2016, 35, 3135-3142. [CrossRef]

61. Montoya, A.; Amaya, C.N.; Belmont, A.; Diab, N.; Trevino, R.; Villanueva, G.; Rains, S.; Sanchez, L.A.; Badri, N.; Otoukesh, S.; et al. Use of non-selective $\beta$-blockers is associated with decreased tumor proliferative indices in early stage breast cancer. Oncotarget 2016, 8, 6446-6460. [CrossRef] [PubMed]

62. Wortsman, J.; Frank, S.; Cryer, P.E. Adrenomedullary response to maximal stress in humans. Am. J. Med. 1984, 77, 779-784. [CrossRef]

63. Axelrod, J.; Reisine, T.D. Stress hormones: Their interaction and regulation. Science 1984, 224, 452-459. [CrossRef]

64. Rebar, R.W.; Spitzer, I.B. The physiology and measurement of hot flushes. Am. J. Obstet. Gynecol. 1987, 156, 1284-1288. [CrossRef] 
65. Collaborative Group on Hormonal Factors in Breast Cancer. Menarche, menopause, and breast cancer risk: Individual participant meta-analysis, including 118964 women with breast cancer from 117 epidemiological studies. Lancet Oncol. 2012, 13, 1141-1151. [CrossRef]

66. Walker, A.K.; Martelli, D.; Ziegler, A.I.; Lambert, G.W.; Phillips, S.E.; Hill, S.J.; Martelli, D.; Sloan, E.K. Circulating epinephrine is not required for chronic stress to enhance metastasis. Psychoneuroendocrinology 2019, 99, 191-195. [CrossRef] [PubMed]

67. Pfaffl, M.W. A new mathematical model for relative quantification in real-time RT-PCR. Nucleic Acids Res. 2001, 29, e45. [CrossRef]

68. Dibner, M.D.; Insel, P.A. Serum catecholamines desensitize beta-adrenergic receptors of cultured C6 glioma cells. J. Biol. Chem. 1981, 256, 7343-7346.

69. Denizot, F.; Lang, R. Rapid colorimetric assay for cell growth and survival. Modifications to the tetrazolium dye procedure giving improved sensitivity and reliability. J. Immunol. Methods 1986, 89, 271-277. [CrossRef]

70. Franken, N.A.P.; Rodermond, H.M.; Stap, J.; Haveman, J.; Van Bree, C. Clonogenic assay of cells in vitro. Nat. Protoc. 2006, 1, 2315-2319. [CrossRef]

71. Soares, A.S.; Costa, V.M.; Diniz, C.; Fresco, P. The combination of Cl-IB-MECA with paclitaxel: A new anti-metastatic therapeutic strategy for melanoma. Cancer Chemother. Pharmacol. 2014, 74, 847-860. [CrossRef] [PubMed]

Publisher's Note: MDPI stays neutral with regard to jurisdictional claims in published maps and institutional affiliations.

(C) 2020 by the authors. Licensee MDPI, Basel, Switzerland. This article is an open access article distributed under the terms and conditions of the Creative Commons Attribution (CC BY) license (http://creativecommons.org/licenses/by/4.0/). 